\title{
German parliament backs stem-cell research
}

\section{Quirin Schiermeier, Munich}

Germany's stem-cell debate took a decisive turn on 30 January, when the parliament voted to let researchers use a limited number of human embryonic stem-cell lines.

The 340-265 vote got a cautious reception from researchers, some of whom are concerned about restrictions in the new law.

Germany will now permit embryonic stem-cell lines created before 30 January 2002 to be imported. Only research on projects that are ranked as a high priority by a new regulatory body will be allowed.

The regulator will ensure that permission is obtained from the parents of the embryo from which the cell line was extracted, and that there are no alternative means of doing the research. Applications will have to be vetted by a new national ethics committee.

The DFG, Germany's main research funding agency, announced last May that it was willing to fund research on stem cells. German law bans the creation (though not the import) of human embryonic stem cells for research purposes. But the DFG chose to delay funding until parliament had debated the issue (see Nature 411, 875; 2001).

Despite the restrictions in the new law, its passage was welcomed by Oliver Brüstle and Otmar Wiestler, the University of Bonn neuroscientists whose application for DFG funding helped spark the debate. Their grant to study the production of neural precursor cells from stem cells was approved the day after the parliamentary decision, but will remain frozen until the law comes into effect. Science minister Edelgard Buhlmann hopes that this will be before the summer.

"The ice is broken," says Brüstle. "We would have preferred a more liberal solution, but the new rules are helpful, provided they will not be used to create further delays." German researchers should have ready access to all the lines listed in the National Institutes of Health (NIH) registry, he says.

Günter Stock, head of research at Berlinbased pharmaceutical company Schering and a vocal supporter of stem-cell research, says, "It is the smallest possible yes, but I am grateful to parliament for the vote." Schering is not yet involved in stem-cell research, but Stock says it will consider cooperating with academic groups or start-up companies as soon as therapies are in sight.

The decision parallels that taken by US President George W. Bush last August, when he ruled that government funds could only be used to pay for research on stem-cell lines already in existence (see Nature 412, 665; 2001). A subsequent survey by the NIH found that 72 lines held by 11 academic institutions and corporations met the criteria.
Wolfgang-Michael Franz, a cardiologist at the University of Munich who has applied for support for a project using stem cells, says that only about 10 of the lines on the NIH list are suitable for research - and that this number has not grown since last summer.

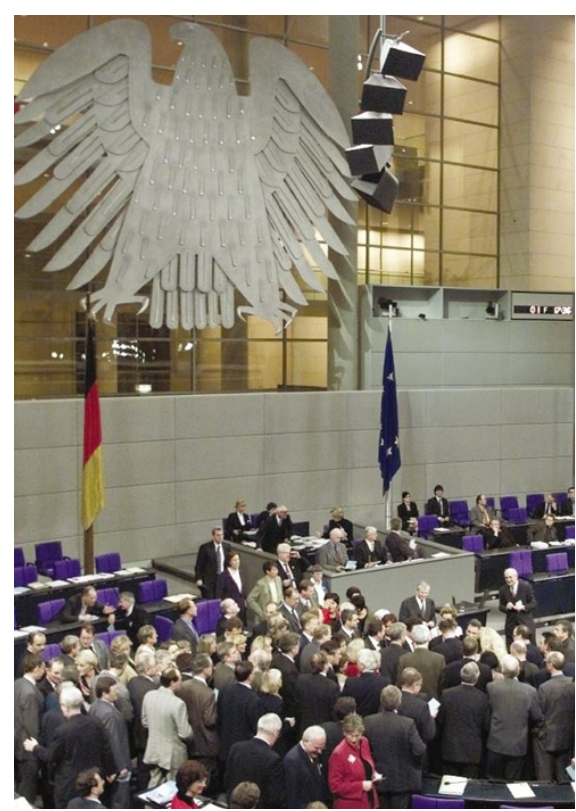

Eagle eye: the German parliament votes to allow stem-cell research, but under strict guidelines.

\section{Drillers dig deep for microbes under the sea floor}

\section{Rex Dalton, San Diego}

Microbes that live beneath the sea floor are the core issue for the latest expedition in the Ocean Drilling Program (ODP), which set sail from San Diego on 27 January.

The research ship will spend eight weeks drilling for sediment samples from the Pacific Ocean, mainly off the coast of Peru.

This is the first time that an ODP cruise has been dedicated to sedimentary biomass, says Steve D'Hondt, an oceanographer at the University of Rhode Island and co-director of the project.

Microbes living in seafloor sediment are thought to make up between one-tenth and one-third of all the living organisms on the planet, but very little is known about them. One of the expedition's goals is to find out how the microbes manage to survive in such an unpromising environment.

The international crew of 25 researchers and a similar number of technicians on board the JOIDES Resolution will recover sea-floor sediment and study the biomass it contains.

Better understanding of the microbes' metabolism should help to explain the interaction among biomass, ocean chemistry and carbon sequestration - a natural process by which carbon is stored in the deep ocean, and which could possibly be tapped artificially to absorb greenhouse gases from the atmosphere.

The Resolution has been fitted with a new laboratory where researchers will initiate their study of the respiration of microbes found in the samples.

Previous, smaller-scale studies have found very little respiration - five to six orders of magnitude less than anticipated from microbial life in the sediment, scientists say. "If one-third of life is in the sea floor, why is there so little respiration?" asks D'Hondt.

The expedition, costing about US\$8 million, is occurring as the ODP — which is supported by the US National Science Foundation and 21 partner agencies around the world - prepares to close down in 2003 after 18 years of operation. A new Integrated Ocean Drilling Program is to take its place, involving a broader international scientific and funding effort.

www.oceandrilling.org

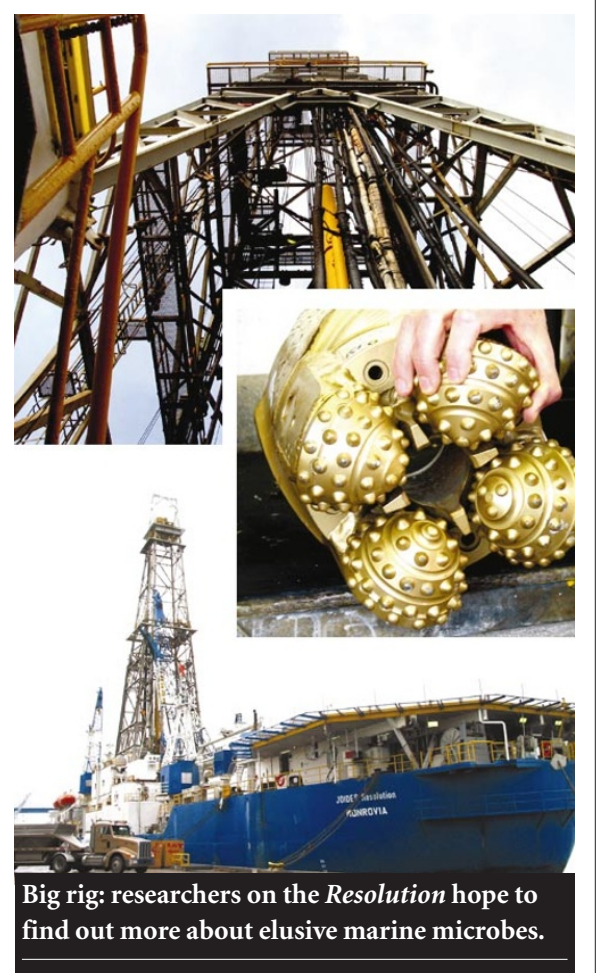

